\title{
Structural and Spectral Properties of 1,2-dihydroxy-9,10-anthraquinone Dye Sensitizer for Solar Cell Applications
}

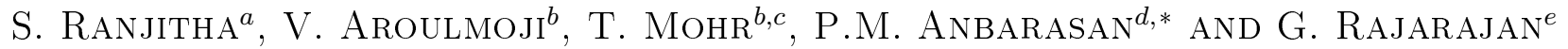 \\ ${ }^{a}$ Velalar College of Engineering and Technology, Thindal, Erode-638012, Tamilnadu, India \\ ${ }^{b}$ Mahendra Educational Institutions, Mallasamudram-637503, Tamil Nadu, India \\ ${ }^{c}$ Department of Energy and Drive Systems, University of Applied Sciences, Ulm, Germany \\ ${ }^{d}$ Department of Physics, Periyar University, Salem-636011, Tamil Nadu, India \\ e Selvam College of Technology, Namakkal-637003, Tamil Nadu, India \\ (Received November 5, 2013; revised version March 5, 2014; in final form March 10, 2014)
}

The geometries, electronic structures, polarizabilities, and hyperpolarizabilities of natural dye sensitizer alizarin from madder fruit was studied based on density functional theory using the hybrid functional B3LYP. Features of the electronic absorption spectra in the visible and near-UV regions were assigned based on time-dependent density function theory calculations. The calculated results suggest three excited states with the lowest excited energies in 1,2-dihydroxy-9,10-anthraquinone and it was due to photoinduced electron transfer processes. The interfacial electron transfer between semiconductor $\mathrm{TiO}_{2}$ electrode and dye sensitizer 1,2-dihydroxy-9,10-anthraquinone is due to an electron injection process from excited dye to the semiconductor conduction band. The importance of hydroxyl group in geometries, electronic structures and spectral properties were reported. DOI: 10.12693 /APhysPolA.126.833

PACS: 88.40.H-, 31.10.+Z, 71.15.Mb, 31.15.ae

\section{Introduction}

Converting solar energy into electricity is generally regarded as the most prospective method to solve the global energy crisis, owing to its huge reserves and pollution-free character. The commercially available solar cells are currently based on inorganic silicon semiconductors. However, their large-scale application has been limited due to the price of high-purity silicon. Organic solar cells, therefore, appear to be a highly promising and cost-effective candidate for the photovoltaic energy industry. In this context, dye-sensitized solar cells (DSSCs) have received widespread attention in recent years because of their high solar-to-electric conversion efficiencies and low costs. The most successful sensitizers employed in these cells are ruthenium polypyridyl complexes; yielding conversion efficiencies up to $11-12 \%$ under standard global air mass 1.5 (AM 1.5) sunlight [1-3]. However, Ru-based dyes are not yet suitable for a large scale DSSCs due to expensive cost of Ru complex compounds and toxicity to environment.

A class of anthraquinone based dyes is interesting to theoretical study as photosensitizer for DSSC. Calculation of the excited state oxidation potential energy as well as electron injection relative to $\mathrm{TiO}_{2}$ conduction band edge is not important only for interpretation of photovoltaic data but also for seeking, too, a new photosensitizer with more suitable electronic property [4]. To investigate the electronic and optical properties, the most favorite method, density functional theory (DFT) is the method of choice according to an accurately described and less computational cost in comparison to other high-

*corresponding author; e-mail: anbarasanpm@gmail.com -level quantum approaches.

Time-dependent DFT (TDDFT) has been widely used to investigate excited state property because the high accuracy is reasonable to correlate with ab initio method but less computational cost [5-8]. In this work, the electronic structure and optical properties, electronic transition, oxidation potential energy, and electron injection force relevant to charge transfer of the anthraquinone dye were investigated using DFT and TDDFT with computational methods were reported. TDDFT method has been widely used to investigate the electronic, optical properties, and the excited state property because of the high accuracy [9-11].

Recently, Marrocchi et al. (2010) reported the synthesis of a series of anthracene containing semiconductors. Anthracene derivatives may exhibit large charge carrier mobility and excellent stability $[12-17]$. To the best of our knowledge, a systematic theoretical study of such compounds has not been reported. The quantum chemical investigation has been performed to explore the optical and electronic properties of a series of different compounds based on anthracene [18]. Different electron side groups were introduced to investigate their effects on the electronic structure. The theoretical knowledge of the HOMO and LUMO energy levels of the dye components is helpful to understand the efficiency of organic solar cells and also useful to synthesis of new efficient dye molecules for DSSC.

In the present paper, we report the changes of the electronic structure and optical properties of 1,2-dihydroxy$-9,10$-anthraquinone (alizarin) induced by an external electric field. Their geometry in each field was then optimized by DFT, B3LYP, and the 6-311G(d) basis set. All chemical quantum calculations were carried out with the Gaussian09 program package. 
TABLE I

Vibrational wave numbers obtained at B3LYP/6-31G(d,p) method [harmonic frequency $\left(\mathrm{cm}^{-1}\right)$, IR intensity ( $\mathrm{K} \mathrm{mmol}^{-1}$ ), Raman intensity (arb.u.)].

\begin{tabular}{|c|c|c|c|}
\hline \multicolumn{2}{|c|}{$\begin{array}{c}\text { FTIR spectra } \\
\text { wave number }\left[\mathrm{cm}^{-1}\right]\end{array}$} & $\begin{array}{l}\text { FT-Raman spectrum } \\
\text { wave number }\left[\mathrm{cm}^{-1}\right]\end{array}$ & \multirow[t]{2}{*}{ Vibrational assignment } \\
\hline Experimental & Theoretical & Theoretical & \\
\hline 319 very weak & 319 & 359 & $\mathrm{C}-\mathrm{C}$ torsion \\
\hline 517 weak & 517 & 518 & $\mathrm{C}=\mathrm{C}-\mathrm{C}$ deformation \\
\hline 663 very weak & 662 & 662 & $=\mathrm{C}-\mathrm{H}$ out-of-plane deformation \\
\hline 679 very weak & 678 & 678 & $=\mathrm{C}-\mathrm{H}$ out-of-plane deformation \\
\hline 776 broad & 775 & 776 & $\mathrm{C}-\mathrm{C}$ bending \\
\hline 990 very weak & 997 & 997 & $\mathrm{C}-\mathrm{C}$ in-of-plane bending \\
\hline 1026 very strong & 1026 & 1026 & $\mathrm{C}-\mathrm{C}$ stretching \\
\hline 1043 very weak & 1042 & 1042 & $\mathrm{C}-\mathrm{C}$ out-of-plane bending \\
\hline 1120 weak & 1120 & 1119 & $\mathrm{C}-\mathrm{H}$ bending \\
\hline 1210 very weak & 1211 & 1210 & $\mathrm{C}-\mathrm{C}$ stretching \\
\hline 1263 very weak & 1262 & 1263 & $\mathrm{C}-\mathrm{C}$ symmetric stretching \\
\hline 1380 weak & 1381 & 1381 & $\mathrm{C}-\mathrm{C}$ asymmetric stretching \\
\hline 1340 very weak & 1342 & 1342 & $\mathrm{C}-\mathrm{H}$ in-plane deformation \\
\hline 1425 very weak & 1426 & 1425 & $\mathrm{C}-\mathrm{H}$ in-plane bending \\
\hline 1436 very weak & 1436 & 1435 & $=\mathrm{C}-\mathrm{H}$ in-plane bending \\
\hline 1440 weak & 1439 & 1438 & $=\mathrm{C}-\mathrm{H}$ out-of-plane bending \\
\hline 1515 very weak & 1516 & 1515 & $\mathrm{C}=\mathrm{C}$ symmetric stretching \\
\hline 1643 weak & 1642 & 1643 & $\mathrm{C}=\mathrm{C}$ asymmetric stretching \\
\hline 1650 very weak & 1652 & 1652 & $\mathrm{C}-\mathrm{H}$ stretching \\
\hline 1738 very strong & 1739 & 1739 & $\mathrm{C}=\mathrm{O}$ symmetric stretching \\
\hline 2337 strong & 2336 & 2336 & $\mathrm{C}=\mathrm{O}$ asymmetric stretching \\
\hline 2849 medium & 2849 & 2850 & $\mathrm{C}-\mathrm{H}$ asymmetric stretching \\
\hline 2977 very weak & 2978 & 2978 & $\mathrm{C}-\mathrm{H}$ symmetric stretching \\
\hline 2917 very weak & 2916 & 2916 & $\mathrm{C}-\mathrm{H}$ asymmetric stretching \\
\hline 2927 very weak & 2926 & 2927 & $\mathrm{C}-\mathrm{H}$ symmetric stretching \\
\hline 2950 medium & 2948 & 2949 & $\mathrm{C}-\mathrm{H}$ asymmetric stretching \\
\hline 3050 very weak & 3048 & 3048 & $=\mathrm{C}-\mathrm{H}$ symmetric stretching \\
\hline 3070 very weak & 3071 & 3071 & $=\mathrm{C}-\mathrm{H}$ asymmetric stretching \\
\hline 3423 broad & 3423 & 3422 & O-H symmetric stretching \\
\hline 3802 very weak & 3803 & 3802 & $\mathrm{O}-\mathrm{H}$ asymmetric stretching \\
\hline
\end{tabular}

\section{Material and methods}

The alizarin (1,2-dihydroxy-9,10-anthraquinone) was obtained from Alpha industry Chemical Company, India, with a purity of greater than $99 \%$ and was used as such without further purifications.

\section{Computational method}

All computational calculations were performed in vacuum, using Gaussian 09 software package, at the B3LYP / $6-311+\mathrm{G}(\mathrm{d}, \mathrm{p})$ level of theory. Six different in-plane conformations of alizarin were identified and investigated $[19,20]$. The differences between conformations are in the $\mathrm{OH}$ group's orientation at $\mathrm{C} 1, \mathrm{C} 9$, and $\mathrm{C} 10$ atoms. The obtained geometries were verified and found to be minima on the potential energy surface by normal mode frequencies. Transitions to the lowest excited singlet electronic states of alizarin were computed by using the TDDFT-B3LYP procedure. The influence of acetonitrile as solvent upon the electronic transitions was approximated by the polarized continuum model PCM. UV-Vis spectral analysis was performed using Chem Craft 1.5, and Gauss sum.

\section{Results and discussion}

\subsection{Geometric structure}

The optimized geometry of the molecule is shown in Fig. 1, and the bond lengths, bond angles are listed in Table I.

\section{2. $U V-V i s$ spectral measurements}

To verify the geometry obtained by the DFT method, detailed analysis of the experimental and theoretical UVVis spectra were performed. The experimental spectra 
of UV-Vis transmission and absorption spectra are presented in Fig. 2. The maximum band for which calculated value is $4500 \mathrm{~nm}$ corresponds to the experimental value of $482 \mathrm{~nm}$. This is essentially a highly occupied-lowly unoccupied molecular orbital (HOMO-LUMO) transition, involving excitation from $n$ to $\pi^{*}$. It was indicated that the transition is associated with significant charge-transfer that characterize the color bands in related compounds, such as alizarin and first strong $\mathrm{UV}-\mathrm{V}$ is band of the parent anthraquinone chromophore [21, 22].

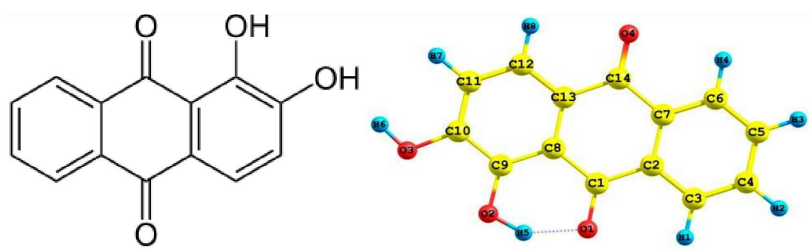

Fig. 1. Optimized geometrical structure of dye alizarin.

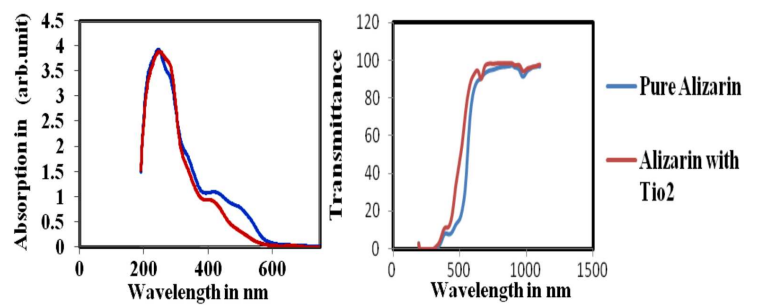

Fig. 2. UV/Vis absorption (left) and transmission (right) spectra of alizarin with $\mathrm{TiO}_{2}$.

\section{IR and Raman spectral analysis}

The Fourier transform infrared (FT-IR) spectrum of 1,2-dihydroxy-9,10-anthraquinone was recorded in the region $400-4000 \mathrm{~cm}^{-1}$ on IFS $66 \mathrm{~V}$ Spectrometer using $\mathrm{KBr}$ pellet technique. The FT-Raman and FT-IR simulated spectra along with observed spectrum of FT-IR are given in Figs. 3-5, respectively. Vibrational wave numbers obtained at B3LYP/6-31G(d,p) method [harmonic frequency $\left(\mathrm{cm}^{-1}\right)$, IR intensity $\left(\mathrm{K} \mathrm{mmol}^{-1}\right)$, Raman intensity (arb.u.)] are shown in Table I. The selected bond lengths (in $\AA$ ), bond angles (in degree) for 1,2-dihydroxy$-9,10$-anthraquinone are shown in Table II.

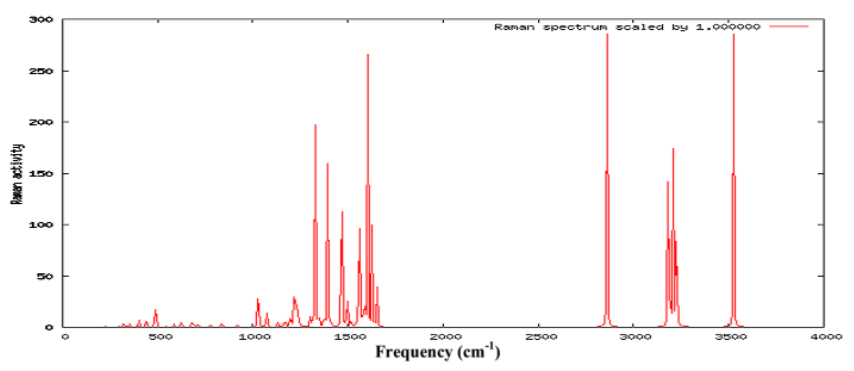

Fig. 3. Theoretical FT-Raman spectrum of alizarin.

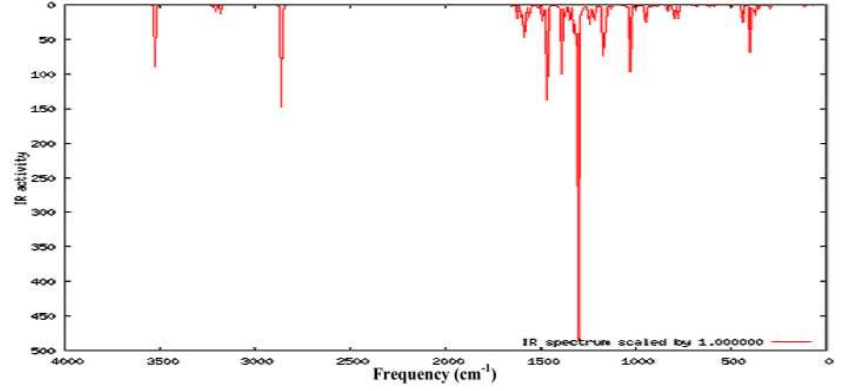

Fig. 4. Theoretical FT-IR spectrum of alizarin.

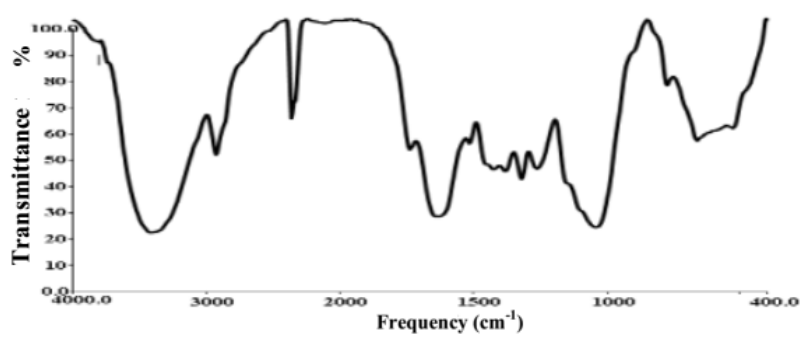

Fig. 5. Experimental FT-IR spectrum of alizarin.

\section{Discussion}

Usually the band around $3802 \mathrm{~cm}^{-1}$ is assigned to $\mathrm{O}-\mathrm{H}$ stretching vibrations. In line with the above conclusion, the bands at 3070 and $3050 \mathrm{~cm}^{-1}$ are assigned to $=\mathrm{C}-\mathrm{H}$ stretching vibrations. The above assignments are in good agreement with the literature values [23-27]. The strong bands at 2337 and $1738 \mathrm{~cm}^{-1}$ are assigned to $\mathrm{C}=\mathrm{O}$ stretching vibrations. The bands at $1436 \mathrm{~cm}^{-1}$ and $1340 \mathrm{~cm}^{-1}$ are assigned to $\mathrm{C}-\mathrm{H}$ in-plane bending. The $\mathrm{C}-\mathrm{C}$ stretching vibrations are assigned to the bands at $1263 \mathrm{~cm}^{-1}$ and $1210 \mathrm{~cm}^{-1}$. The band at $517 \mathrm{~cm}^{-1}$ is assigned to $\mathrm{C}=\mathrm{C}-\mathrm{C}$ deformation vibrations. The torsion vibrations usually occur below $200 \mathrm{~cm}^{-1}$. The bands at 2950, 2927, and $2977 \mathrm{~cm}^{-1}$ are assigned to $\mathrm{C}-\mathrm{H}$ stretching vibrations. The weak bands at 1643 and $1515 \mathrm{~cm}^{-1}$ are assigned to $\mathrm{C}=\mathrm{C}$ stretching while the bands at 1380 and $1026 \mathrm{~cm}^{-1}$ are assigned to $\mathrm{C}-\mathrm{C}$ stretching vibrations.

\section{Electronic absorption spectra and sensitized mechanism}

Many organic molecules that contain conjugated $\pi$ electrons are characterized by hyperpolarizabilities and were analyzed by means of vibrational spectroscopy. In most cases even in the absence of inversion symmetry, the strongest bands in the Raman spectrum is weak in their spectrum and vice versa. Then $n \rightarrow \pi^{*}$ electron shift from the donor to acceptor can make the molecule highly polarized through the single-double bond path when it changes from the ground state to first excited state. The analysis of wave function indicates that the electronic absorption and the transition from the ground state to 
TABLE II

The selected bond lengths (in $\AA$ ), bond angles (in degree) for alizarin.

\begin{tabular}{|c|c|c|c|}
\hline Bonding & $\begin{array}{c}\text { Parameters } \\
\text { B3LYP/ } \\
6-311++\mathrm{G}(\mathrm{d}, \mathrm{p}) \\
\text { bond length }[\AA]\end{array}$ & Bonding & $\begin{array}{c}\text { Parameters } \\
\text { B3LYP/ } \\
6-311++\mathrm{G}(\mathrm{d}, \mathrm{p}) \\
\left.\text { bond angle [ }{ }^{\circ}\right]\end{array}$ \\
\hline $\mathrm{C}_{1}-\mathrm{C}_{2}$ & 1.2788 & $\mathrm{O}_{1}-\mathrm{C}_{2}-\mathrm{C}_{3}$ & 120 \\
\hline $\mathrm{C}_{2}-\mathrm{C}_{3}$ & 1.4741 & $\mathrm{O}_{1}-\mathrm{C}_{2}-\mathrm{C}_{9}$ & 120 \\
\hline $\mathrm{C}_{2}-\mathrm{C}_{9}$ & 1.4587 & $\mathrm{O}_{3}-\mathrm{C}_{2}-\mathrm{C}_{9}$ & 118 \\
\hline $\mathrm{C}_{3}-\mathrm{C}_{4}$ & 1.4024 & $\mathrm{C}_{2}-\mathrm{C}_{3}-\mathrm{C}_{8}$ & 120 \\
\hline $\mathrm{C}_{3}-\mathrm{C}_{8}$ & 1.4107 & $\mathrm{C}_{3}-\mathrm{C}_{4}-\mathrm{C}_{5}$ & 120 \\
\hline $\mathrm{C}_{4}-\mathrm{C}_{5}$ & 1.3944 & $\mathrm{C}_{3}-\mathrm{C}_{4}-\mathrm{H}_{19}$ & 118 \\
\hline $\mathrm{C}_{5}-\mathrm{C}_{6}$ & 1.404 & $\mathrm{C}_{5}-\mathrm{C}_{4}-\mathrm{H}_{19}$ & 121 \\
\hline $\mathrm{C}_{6}-\mathrm{C}_{7}$ & 1.3956 & $\mathrm{C}_{4}-\mathrm{C}_{5}-\mathrm{C}_{6}$ & 120 \\
\hline $\mathrm{C}_{7}-\mathrm{C}_{8}$ & 1.4002 & $\mathrm{C}_{4}-\mathrm{C}_{5}-\mathrm{H}_{20}$ & 119 \\
\hline $\mathrm{C}_{8}-\mathrm{C}_{17}$ & 1.4868 & $\mathrm{C}_{6}-\mathrm{C}_{5}-\mathrm{H}_{20}$ & 120 \\
\hline $\mathrm{C}_{9}-\mathrm{C}_{10}$ & 1.4121 & $\mathrm{C}_{5}-\mathrm{C}_{6}-\mathrm{C}_{7}$ & 120 \\
\hline $\mathrm{C}_{9}-\mathrm{C}_{16}$ & 1.4215 & $\mathrm{C}_{7}-\mathrm{C}_{6}-\mathrm{H}_{21}$ & 119 \\
\hline $\mathrm{C}_{10}-\mathrm{C}_{11}$ & 1.363 & $\mathrm{C}_{6}-\mathrm{C}_{7}-\mathrm{C}_{8}$ & 120 \\
\hline $\mathrm{C}_{11}-\mathrm{C}_{12}$ & 1.4167 & $\mathrm{C}_{6}-\mathrm{C}_{7}-\mathrm{H}_{22}$ & 120 \\
\hline $\mathrm{C}_{12}-\mathrm{C}_{13}$ & 1.3881 & $\mathrm{C}_{8}-\mathrm{C}_{7}-\mathrm{H}_{22}$ & 118 \\
\hline $\mathrm{C}_{12}-\mathrm{C}_{14}$ & 1.3887 & $\mathrm{C}_{3}-\mathrm{C}_{8}-\mathrm{C}_{7}$ & 119 \\
\hline $\mathrm{C}_{14}-\mathrm{C}_{15}$ & 1.4006 & $\mathrm{C}_{3}-\mathrm{C}_{8}-\mathrm{C}_{17}$ & 121 \\
\hline $\mathrm{C}_{15}-\mathrm{C}_{16}$ & 1.3904 & $\mathrm{C}_{7}-\mathrm{C}_{8}-\mathrm{C}_{17}$ & 119 \\
\hline $\mathrm{C}_{16}-\mathrm{C}_{17}$ & 1.4778 & $\mathrm{C}_{2}-\mathrm{C}_{9}-\mathrm{C}_{10}$ & 118 \\
\hline $\mathrm{C}_{1}-\mathrm{H}_{23}$ & 1.6124 & $\mathrm{C}_{2}-\mathrm{C}_{9}-\mathrm{C}_{16}$ & 120 \\
\hline $\mathrm{C}_{4}-\mathrm{H}_{19}$ & 1.0839 & $\mathrm{C}_{10}-\mathrm{C}_{9}-\mathrm{C}_{16}$ & 120 \\
\hline $\mathrm{C}_{5}-\mathrm{H}_{20}$ & 1.0848 & $\mathrm{C}_{9}-\mathrm{C}_{10}-\mathrm{O}_{11}$ & 122 \\
\hline $\mathrm{C}_{6}-\mathrm{H}_{21}$ & 1.0849 & $\mathrm{C}_{9}-\mathrm{C}_{10}-\mathrm{C}_{12}$ & 119 \\
\hline $\mathrm{C}_{7}-\mathrm{H}_{22}$ & 1.0841 & $\mathrm{O}_{11}-\mathrm{C}_{10}-\mathrm{C}_{12}$ & 118 \\
\hline $\mathrm{C}_{10}-\mathrm{O}_{11}$ & 1.363 & $\mathrm{C}_{10}-\mathrm{O}_{11}-\mathrm{H}_{23}$ & 107 \\
\hline $\mathrm{O}_{11}-\mathrm{H}_{23}$ & 1.0295 & $\mathrm{C}_{10}-\mathrm{C}_{12}-\mathrm{O}_{13}$ & 116 \\
\hline $\mathrm{C}_{12}-\mathrm{O}_{13}$ & 1.3881 & $\mathrm{C}_{10}-\mathrm{C}_{12}-\mathrm{C}_{14}$ & 119 \\
\hline $\mathrm{O}_{13}-\mathrm{H}_{24}$ & 0.994 & $\mathrm{C}_{13}-\mathrm{C}_{12}-\mathrm{C}_{14}$ & 123 \\
\hline \multirow[t]{13}{*}{$\mathrm{C}_{17}-\mathrm{O}_{18}$} & 1.2568 & $\mathrm{C}_{12}-\mathrm{O}_{13}-\mathrm{H}_{24}$ & 111 \\
\hline & & $\mathrm{C}_{12}-\mathrm{C}_{14}-\mathrm{C}_{15}$ & 121 \\
\hline & & $\mathrm{C}_{12}-\mathrm{C}_{14}-\mathrm{H}_{25}$ & 119 \\
\hline & & $\mathrm{C}_{15}-\mathrm{C}_{14}-\mathrm{H}_{25}$ & 119 \\
\hline & & $\mathrm{C}_{14}-\mathrm{C}_{15}-\mathrm{C}_{16}$ & 120 \\
\hline & & $\mathrm{C}_{14}-\mathrm{C}_{15}-\mathrm{H}_{26}$ & 120 \\
\hline & & $\mathrm{C}_{16}-\mathrm{C}_{15}-\mathrm{H}_{26}$ & 119 \\
\hline & & $\mathrm{C}_{9}-\mathrm{C}_{16}-\mathrm{C}_{15}$ & 119 \\
\hline & & $\mathrm{C}_{9}-\mathrm{C}_{16}-\mathrm{C}_{17}$ & 121 \\
\hline & & $\mathrm{C}_{15}-\mathrm{C}_{16}-\mathrm{C}_{17}$ & 119 \\
\hline & & $\mathrm{C}_{8}-\mathrm{C}_{17}-\mathrm{C}_{16}$ & 117 \\
\hline & & $\mathrm{C}_{8}-\mathrm{C}_{17}-\mathrm{C}_{18}$ & 120 \\
\hline & & $\mathrm{C}_{16}-\mathrm{C}_{17}-\mathrm{C}_{18}$ & 121 \\
\hline
\end{tabular}

first excited state is mainly described by one electron excitation from the highest occupied molecular orbital to the lowest unoccupied molecular orbital. Figure 6 shows the frontier molecular orbital energies and corresponding density of state (DOS) spectrum of 1,2-dihydroxy-9,10-anthraquinone.

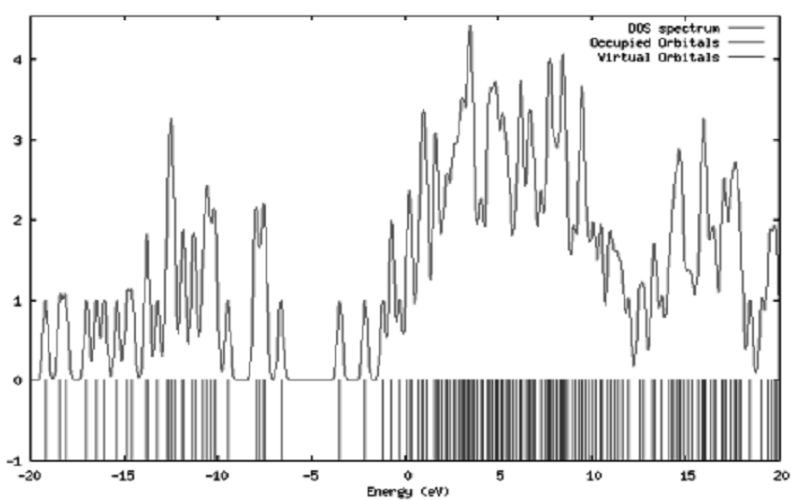

Fig. 6. The frontier molecular orbital energies and corresponding density of state (DOS) spectrum of alizarin.

The calculated UV-Vis spectra analysis of 1,2-dihydroxy-9,10-anthraquinone in acetonitrile at TD-DFT $(6-311+\mathrm{G}(\mathrm{d}, \mathrm{p}))$ shows that the maximum absorption wavelength of $449.6 \mathrm{~nm}$ corresponds to the electronic transition between $n \rightarrow \pi^{*}$ transition (Fig. 7). In order to obtain the microscopic information about the electronic transitions the corresponding molecular properties are checked [28].

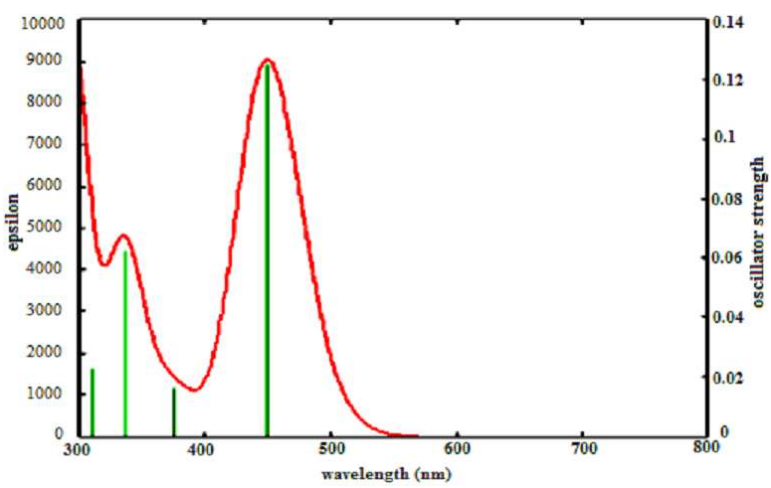

Fig. 7. UV-Vis electronic absorption spectra of alizarin.

According to B3LYP $/ 6-311+\mathrm{G}(\mathrm{d}, \mathrm{p})$ calculation, the energy gap $(\Delta E)$ transition from HOMO to LUMO of the molecule is about $3.13 \mathrm{eV}$. The highest occupied molecular orbitals are localized mainly on the ring. The absorption in visible and near UV-region are most important for photo-to-current conversion, so only the HOMO $\rightarrow$ LUMO transitions of absorption band in visible- near UV region are listed in Table III. This indicates that the transitions are photoinduced charge transfer processes, thus the excitations generate charge separated states which favor the electron injection from the excited dye state to semiconductor surface.

The solar energy to electricity conversion efficiency $(\eta)$

$$
\eta(\%)=\frac{J_{\mathrm{sc}}\left[\mathrm{mA} \mathrm{cm}^{-2}\right] V_{\mathrm{oc}}[\mathrm{V}] f f}{I_{0}\left[\mathrm{~mW} \mathrm{~cm}^{-2}\right]} \times 100 .
$$

According to the sensitized mechanism single electron 
and single state approximation there is energy relationship. So the $V_{\text {oc }}$ may be obtained applying the formula $V_{\mathrm{oc}}=\left(E_{\mathrm{LUMO}}-E_{\mathrm{CB}}\right) / e . J_{\mathrm{sc}}, V_{\mathrm{oc}}$, and $f f$ are only obtained by experiment, the relationship among these quantities and the electronic structure of dye is still unknown. According to the sensitized mechanism (electron injected from the excited dyes to the semiconductor conduction band) and single electron and single state approximation, there is an energy relationship. The $J_{\text {sc }}$ is determined by two processes, one is the rate of electron injection from the excited dyes to the conduction band of semiconductor, and the other is the rate of redox between the excited dyes and electrolyte. This indicates that most of excited states of 1,2-dihydroxy-9,10-anthraquinone have larger absorption coefficient, and then with shorter life time for the excited states, so it results in the higher electron injection rate which leads to the larger $J_{\mathrm{sc}}$ of 1,2-dihydroxy-9,10-anthraquinone.

TABLE III

Computed excitation energies, electronic transition configurations and oscillator strengths $(f)$ or the optical transitions with $f>0.1247$ of the absorption bands in visible and near-UV region for alizarin.

\begin{tabular}{|c|c|c|c|c|c|}
\hline $\begin{array}{l}\text { No. of } \\
\text { states }\end{array}$ & $\begin{array}{l}\text { Energy } \\
{\left[\mathrm{cm}^{-1}\right]}\end{array}$ & $\begin{array}{l}\text { Wavelength } \\
\text { [nm] }\end{array}$ & $\begin{array}{l}\text { Oscillator } \\
\text { strength } f\end{array}$ & \multicolumn{2}{|c|}{ Electronic transitions configuration } \\
\hline 1 & 22239.28 & 449.6549 & 0.1247 & $\mathrm{HOMO}(62) \rightarrow$ LUMO $63(82 \%)$ & \\
\hline 2 & 22698.21 & 440.5633 & 0 & $61 \rightarrow 63(91 \%)$ & $61 \rightarrow 64(2 \%)$ \\
\hline 3 & 26349.51 & 379.5137 & 0 & $58 \rightarrow 63(91 \%)$ & $61 \rightarrow 64(-3 \%)$ \\
\hline 4 & 26676.97 & 374.8551 & 0.0161 & $60 \rightarrow 63(90 \%)$ & \\
\hline 5 & 29709.64 & 336.5911 & 0.0623 & $59 \rightarrow 63(86 \%)$ & $57 \rightarrow 64(4 \%), 60 \rightarrow 64(2 \%)$ \\
\hline 6 & 32306.76 & 309.5327 & 0.0226 & HOMO $62 \rightarrow 63(87 \%)$ & \\
\hline 7 & 34106.2 & 293.2019 & 0.1287 & $57 \rightarrow$ LUMO (78\%) & $60 \rightarrow 65(-2 \%)$ \\
\hline 8 & 35324.1 & 283.0928 & 0 & $61 \rightarrow 64(91 \%)$ & $58 \rightarrow \operatorname{LUMO}(3 \%), 61 \rightarrow 63(-3 \%)$ \\
\hline 9 & 38523.73 & 259.5803 & 0.1115 & $60 \rightarrow 64(38 \%), 62>65(49 \%)$ & $57 \rightarrow 64(-2 \%)$ \\
\hline 10 & 39842.45 & 250.9886 & 0 & $58 \rightarrow 63(95 \%)$ & \\
\hline 11 & 40393.33 & 247.5656 & 0.523 & $\begin{array}{c}60 \rightarrow 64(43 \%) \\
\mathrm{HOMO} \rightarrow 65(-31 \%)\end{array}$ & $\begin{array}{c}57 \rightarrow 64(7 \%), 59 \rightarrow 65(5 \%) \\
\quad 60 \rightarrow 66(-3 \%)\end{array}$ \\
\hline 12 & 41210.38 & 242.6573 & 0.0295 & $59 \rightarrow 64(84 \%)$ & $59 \rightarrow 66(2 \%)$ \\
\hline 13 & 41664.47 & 240.0127 & 0.0004 & $\mathrm{HOMO} \rightarrow 67(97 \%)$ & \\
\hline 14 & 42565.4 & 234.9326 & 0.0059 & $\begin{aligned} 55 & \rightarrow 64(67 \%) \\
59 & \rightarrow 65(10 \%)\end{aligned}$ & $\begin{array}{c}56 \rightarrow \text { LUMO }(-4 \%), 60 \rightarrow 64(-2 \%), \\
\text { HOMO } \rightarrow 65(7 \%)\end{array}$ \\
\hline 15 & 42984 & 232.6447 & 0.027 & $\begin{array}{l}56 \rightarrow \text { LUMO }(44 \%) \\
\text { HOMO } \rightarrow 65(42 \%)\end{array}$ & $54 \rightarrow \operatorname{LUMO}(3 \%), 60 \rightarrow 65(-2 \%)$ \\
\hline 16 & 43905.09 & 227.764 & 0.0001 & $61 \rightarrow 65(96 \%)$ & \\
\hline 17 & 44789.08 & 223.2687 & 0.0385 & $\begin{array}{l}56 \rightarrow \text { LUMO }(40 \%) \\
\mathrm{HOMO} \rightarrow 66(-39 \%)\end{array}$ & $60 \rightarrow 65(6 \%)$ \\
\hline 18 & 45282.7 & 220.8349 & 0 & $55 \rightarrow$ LUMO $(94 \%)$ & \\
\hline 19 & 47229.73 & 211.731 & 0 & $\begin{aligned} 58 & \rightarrow 65(10 \%) \\
61 & \rightarrow 66(85 \%)\end{aligned}$ & $53 \rightarrow \operatorname{LUMO}(2 \%)$ \\
\hline 20 & 47465.25 & 210.6804 & 0.0003 & $\begin{array}{l}\text { HOMO } \rightarrow 68(81 \%) \\
\text { HOMO } \rightarrow 70(-11 \%)\end{array}$ & $\mathrm{HOMO} \rightarrow 69(-5 \%)$ \\
\hline
\end{tabular}

\section{The light harvesting efficiency}

Light harvesting efficiency (LHE) is the efficiency of dye response to light. It is another factor which indicates the efficiency of DSSC. The LHE of the dye should be as high as feasible to maximize the photocurrent response. Higher oscillator strength of new designed sensitizer is due to better $\pi$-conjugation. The calculated value of the LHE of the main absorption peaks with the oscillator strength is reported in Table III. The dyes will convert more light to electrical energy. Only the transitions with considerable oscillator strengths are given. The electron distribution of the HOMO orbital is delocalized on the $\pi$-system with the maximum electron density present on the benzene rings and quinone in all new designed sensitizers. It should be noted that the LUMO orbitals have highest compositions on anchoring group and benzene ring of the acceptor side in all new designed sensitizers. Therefore, electrons will move from donor to acceptor during the HOMO-LUMO excitation resulting by light absorption $[29,30]$. Figure 8 shows that the isodensity plots (isodensity contour $=0.02$ a.u.) of the frontier or- 
bitals of the dye 1,2-dihydroxy-9,10-anthraquinone corresponding orbital energies.

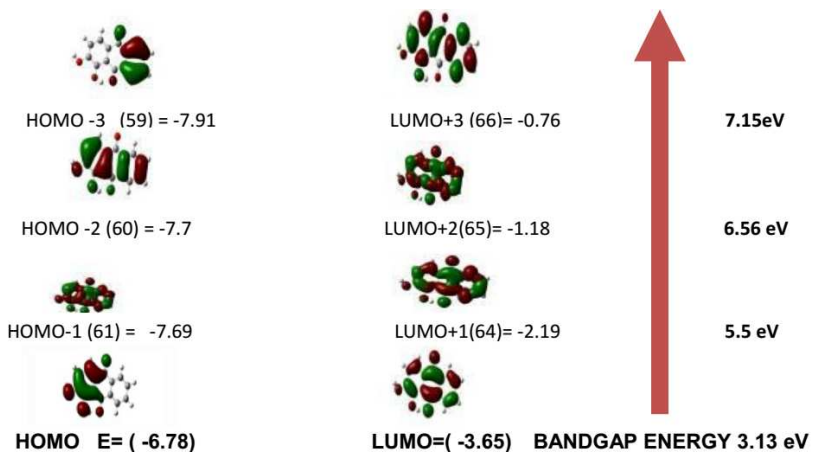

Fig. 8. Isodensity plots (isodensity contour = 0.02 a.u.) of the frontier orbitals of the dye alizarin corresponding orbital energies.

\section{NLO Properties}

The interactions of electromagnetic radiation in some molecules can give a non-linear optical (NLO) effect which shows some alterations in phase, frequency, and amplitude from the incident field. NLO is an important concept in current research scenario because of its vast applications to telecommunications, optical switch, and signal processing. This means that polarizability, the total static dipole moment $(\mu)$ and the first order hyperpolarizability are calculated by using $x, y, z$ components. Theoretical calculation provides another method to investigate substantial characters of materials. As hyperpolarizability is difficult to measure directly, computational calculation is an alternate choice. The first order hyperpolarizability of title molecular system and related properties are calculated using B3LYP $/ 6-31+\mathrm{G}(\mathrm{d}, \mathrm{p})$ basis set, based on the finite field approach. In the presence of an applied electric field, the energy of a system is a function of the electric field. First order hyperpolarizability is a third rank tensor that can be described by a $3 \times 3 \times 3$ matrix. The 27 components of the $3 \mathrm{D}$ matrix can be reduced to 10 components due to the Kleinman symmetry [31]. It can be given in the lower tetrahedral format. It is obvious that the lower part of $3 \times 3 \times 3$ matrices is a tetrahedral.

The total static dipole moment and the mean first order hyperpolarizability, using the $x, y, z$ components, they are defined as $\beta_{\text {total }}=\beta_{x}^{2}+\left(\beta_{y}^{2}+\beta_{z}^{2}\right)^{1 / 2}$. To complete equation for calculating the first GAUSSIAN 03W output is given as $\beta_{\text {total }}=\left(\left(\beta_{x x x}+\beta_{x y y}+\beta_{x z z}\right)^{2}+\left(\beta_{y y y}+\right.\right.$ $\left.\beta_{y z z}+\beta_{y x x}\right)^{2}+\left(\beta_{z z z}+\beta_{z x x}+\beta_{z y y}\right)^{2}$. The total molecular dipole moment and mean first hyperpolarizability are found to be $1.6845 \mathrm{D}$ and $3.5724 \times 10^{-30}$ esu respectively and are shown in Tables IV and V. The connection between the electric dipole moments of an organic molecule having donor-acceptor substituent and first order hyperpolarizability is widely recognized in the literature [32].
TABLE IV

Hyperpolarizability $(\beta)$ results of dye sensitizers.

\begin{tabular}{c|c}
\hline \hline Parameters & B3LYP $/ 6-311+\mathrm{G}(\mathrm{d}, \mathrm{p})$ \\
\hline$\beta_{x x x}$ & 11.0813 \\
$\beta_{x y y}$ & 5.4277 \\
$\beta_{x z z}$ & 12.5341 \\
$\beta_{y y y}$ & -24.0348 \\
$\beta_{y z z}$ & -4.0565 \\
$\beta_{y x x}$ & 62.1065 \\
$\beta_{z z z}$ & 0.9097 \\
$\beta_{z x x}$ & 3.0207 \\
$\beta_{z y y}$ & 1.0609
\end{tabular}

total first order

hyperpolarizability

$2.7309 \times 10^{-30} \mathrm{esu}$

TABLE V

Crystal cell parameters and dipole moment of the dye sensitizers.

\begin{tabular}{c|c|c|c|c}
\hline $\begin{array}{c}\text { Cell } \\
\text { parameter }\end{array}$ & $a[\AA]$ & $b[\AA]$ & $c[\AA]$ & $\begin{array}{c}\text { Space } \\
\text { group }\end{array}$ \\
\hline $\begin{array}{c}\text { dipole } \\
\text { moment } \\
\text { (field- } \\
\text {-independent } \\
\text { basis, D): }\end{array}$ & 6.5036 & 0.129676 & 0.49937 & $P_{11}$ \\
dipole \\
moment \\
$2.1311 \mathrm{D}$
\end{tabular}

\section{Hyperpolarizability $(\beta)$ and crystal cell parameter}

The components of first order hyperpolarizability and the crystal parameters of the title compound are reported in Tables IV and V. The first order hyperpolarizability of 1,2-dihydroxy-9,10-anthraquinone is $2.7309 \times 10^{-30} \mathrm{esu}$ which is 9 times greater than urea $(\beta=0.3727 \times$ $10^{-30} \mathrm{esu}$ ) which shows that it has NLO property. The crystal structure is determined in DFT using PBC calculation. The crystal symmetry confirms that the material has non-centrosymmetric structure as shown in Fig. 9.

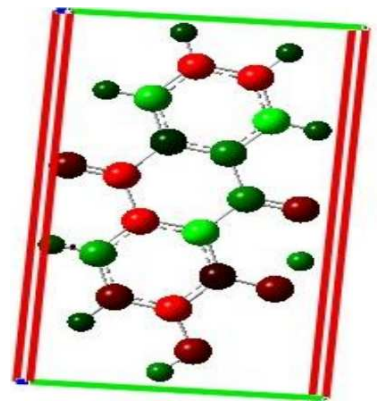

Fig. 9. Crystal structure of alizarin.

\section{Conclusion}

The geometries, electronic structures, polarizabilities and hyperpolarizabilities of dye alizarin were studied by using density functional theory with hybrid functional 
B3LYP, and the UV-Vis spectra were investigated by using TDDFT methods. The NBO results suggest that 1,2-dihydroxy-9,10-anthraquinone is a (D-p-A) system. The calculated isotropic polarizability of 1,2-dihydroxy$-9,10$-anthraquinone is $3.5724 \times 10^{-30}$ esu. The calculated hyperpolarizability anisotropy invariant is $2.7309 \times$ $10^{-30}$ esu. The electronic absorption spectral features in visible and near-UV region were assigned based on the qualitative agreement to TDDFT calculations. The absorptions were all described to $n \rightarrow \pi^{*}$ transition. The three excited states with the lowest excited energies of 1,2-dihydroxy-9,10-anthraquinone is photoinduced electron transfer processes that contributes sensitization of photocurrent conversion processes.

The interfacial electron transfer between semiconductor $\mathrm{TiO}_{2}$ electrode and dye sensitizer 1,2-dihydroxy$-9,10$-anthraquinone is due to electron injection process from excited dye as donor to the semiconductor conduction band. Based on the analysis of geometries, electronic structures and spectrum properties of 1,2-dihydroxy-9,10-anthraquinone, the role of quinone in 1,2-dihydroxy-9,10-anthraquinone is as follows: it enlarges the distance between electron donor group and semiconductor surface and decreases the timescale of the electron injection rate, giving in result lower conversion efficiency. This indicates that the choice of the appropriate conjugate bridge in dye sensitizer is very important to improve the performance of DSSC.

\section{Acknowledgments}

The authors are also thankful to the Centre for Nanoscience and Nanotechnology, Periyar University, Salem, Tamilnadu, India, for their continuous motivation to carry out this research. One the author (S.R.) thanks to Mahendra Educational Institutions and Velalar College of Engineering and Technology for providing necessary facilities to carry out this work.

\section{References}

[1] H.P. Dai, K. Shiu, Electrochim. Acta 43, 2709 (1998).

[2] T. Grygar, ک̌. Kučková, D. Hradil, J. Hradilová, J. Solid State Electrochem. 7, 706 (2003).

[3] B. O'Regan, M. Gratzel, Nature 353, 737 (1991).

[4] M. Gratzel, Nature 414, 338 (2001).

[5] N.G. Park, K. Kim, Phys. Status Solidi A 205, 1895 (2008).

[6] Y. Chiba, A. Islam, Y. Watanabe, R. Komiya, N. Koide, L. Han, Jpn. J. Appl. Phys. 45, L638 (2006).

[7] C.R. Zhang, H.S. Chen, G.H. Wang, Chem. Res. Chin. U 20, 640 (2004).

[8] Y. Sun, X. Chen, L. Sun, X. Guo, W. Lu, Chem. Phys. Lett. 381, 397 (2003).

[9] O. Christiansen, J. Gauss, J.F. Stanton, Chem. Phys. Lett. 305, 147 (1999).
[10] P.M. Anbarasan, P. Senthil Kumar, K. Vasudevan, S. Moorthy Babu, V. Aroulmoji, Acta Phys. Pol. A 119, 395 (2011).

[11] D. Jacquemin, J. Preat, M. Charlot, V. Wathelet, J.M. Andre, E.A. Perpète, J. Chem. Phys. 121, 1736 (2004).

[12] E.A. Perpète, V. Wathelet, J. Preat, C. Lambert, D. Jacquemin, J. Chem. Theor. Comput. 2, 434 (2006).

[13] D. Jacquemin, V. Wathelet, J. Preat, E.A. Perpète, Spectrochim. Acta A 67A, 334 (2007).

[14] D. Jacquemin, X. Assfeld, J. Preat, E.A. Perpète, Mol. Phys. 105, 325 (2007).

[15] D. Jacquemin, E.A. Perpète, I. Ciofini, C. Adamo, Acc. Chem. Res. 42, 326 (2009); J. Fabian, Dyes Pigm. 84, 36 (2010).

[16] R. Chencier, Madder Red: A History of Luxury and Trade, Curzon Press, Richmond 2000.

[17] D. Jacquemin, E. Brémond, A. Planchat, I. Ciofini, C. Adamo, Chem. Theory Comput. 7, 1882 (2011).

[18] N. Belghiti, M. Bennani, M. Hamidi, S.M. Bouzzine, M. Bouachrine, Afr. J. Pure Appl. Chem. 6, 164 (2012).

[19] L. Shen, H.-F. Ji, H.-Y. Zhang, J. Mol. Struct. THEOCHEM 851, 220 (2008).

[20] T. Joseph, C.H.T. Varghese, Y. Panicker, T. Thiemann, K. Viswanathan, C. Van Alsenoy, T.K. Manojkumar, Spectrochim. Acta Part A, Mol. Biomol. Spectrosc. 117, 413 (2014).

[21] D. Jacquemin, J. Preat, M. Charlot, V. Wathelet, J.-M. André, E.A. Perpète, J. Chem. Phys. 121, $1736(2004)$

[22] D. Guillaumont, S. Nakamura, Dyes Pigm. 46, 85 (2000).

[23] P.L. Polavarapu, J. Phys. Chem. 94, 8106 (1990).

[24] G. Keresztury, S. Holly, J. Varga, G. Besenyei, A.Y. Wang, J.R. Durig, Spectrochim. Acta A 49, 1993 (2007).

[25] P. Nallasamy, P.M. Anbarasan, S. Mohan, Turk. J. Chem. 26, 105 (2002).

[26] Handbook of Vibrational Spectroscopy, Eds. J.M. Chalmers, P.R. Griffiths, Vol. 1, Wiley, Chichester 2001, p. 71.

[27] J. Karpagam, N. Sundaraganesan, S. Sebastian, S. Manoharan, M.Z. Kurt, J. Raman Spectrosc. 41, $53(2010)$.

[28] D.F. Waston, G.J. Meyer, Ann. Rev. Phys. Chem. 56, 119 (2005).

[29] R. Sánchez-de-Armas, M.A. San-Miguel, J. Oviedo, J. Fdez. Sanz, Comput. Theor. Chem. 975, 99 (2011).

[30] W.R. Duncan, O.V. Prezhdo, J. Phys. Chem. B 109, 365 (2005).

[31] D.A. Kleinman, Phys. Rev. 126, 1977 (1962).

[32] S. Arulmozhi, M. Victor Antony Raj, J. Madhavan, Der Chemica Sinica 2, 158 (2011). 